\title{
The impact of audit rotation on the comparability of financial
}

\section{reports ${ }^{\star, * *}$}

\author{
Allison Manoel de Sousa ${ }^{1}$ \\ (D) https://orcid.org/0000-0002-5959-6078 \\ Email: allison.msousa@gmail.com
}

\author{
Alex Mussoi Ribeiro ${ }^{2}$ \\ (D) https://orcid.org/0000-0003-3389-9713 \\ Email: alex.mussoi@ufsc.br \\ Ernesto Fernando Rodrigues Vicente ${ }^{2}$ \\ (D) https://orcid.org/0000-0002-1992-9982 \\ Email: ernesto.vicente@ufsc.br \\ ${ }^{1}$ Universidade Federal do Paraná, Programa de Pós-Graduação em Contabilidade, Curitiba, PR, Brazil \\ ${ }^{2}$ Universidade Federal de Santa Catarina, Programa de Pós-Graduação em Contabilidade, Florianópolis, SC, Brazil
}

Received on 03.23.2020 - Desk acceptance on 04.04.2020 - 2nd version approved on 01.18.2021 - Ahead of print on 07.23.2021 Editor-in-Chief: Fábio Frezatti

Associate Editor: Eliseu Martins

\begin{abstract}
This study aims to assess the effect of the rotation and tenure of audit firm and audit partner on the comparability and consistency of financial reports. Several studies have addressed the effect of auditor rotation on the quality of financial reports, but none of them focused specifically on the impact on the comparability and consistency of financial reports. Around the world, the impact of mandatory rotation of audit partner and audit firm is being discussed in academia and regulatory bodies. The peculiarity of the Brazilian regulatory environment allows us to contribute to the discussions on the effects of implementing mandatory auditor rotation. Our sample included 50 companies for which we analyzed data from 2012 to 2018. To measure comparability, we used the similarity of the accounting function model by DeFranco, Kothari and Verdi (2011), and to measure consistency we used the adaptations to this model proposed by Ribeiro (2014). For data analysis, we used descriptive statistics and multivariate panel analysis. Our results suggest that the rotation (mandatory and voluntary) of audit firm and audit partner does not affect the comparability and consistency of financial reports. Results also suggest that auditor-client relationships of up to three years contribute to a significant increase in comparability and consistency, indicating that mandatory rotation does not impair investors' ability to compare the information concerning their investments. In addition, regulators are shown that a possible reduction in the mandatory rotation term (from five to three years, as in Italy) would be in line with market practices and would imply an increase in the comparability and consistency of financial information.
\end{abstract}

Keywords: comparability, auditor rotation, consistency.

Correspondence address

Allison Manoel de Sousa

Federal University of Paraná, Graduate Program in Accounting

Avenida Prefeito Lothário Meissner, 632 - CEP 80210-170

Jardim Botânico - Curitiba - PR - Brasil

* This paper was presented at the XIX USP International Conference in Accounting, São Paulo, SP, Brazil, July 2019.

** This study was carried out with the support of the Coordination for the Improvement of Higher Education Personnel (Capes) - Financing Code 001. 


\section{INTRODUCTION}

Since its inception, the external auditor's role is to bring credibility to the information companies provide about their economic and financial performance. As a result, they reduce information risk ( $\mathrm{Lu} \&$ Sivaramakrishnan, 2009) and can contribute to a more efficient capital allocation in market economies.

One aspect directly related to the efficiency (quality) of the services provided by external auditors is their independence from the client firm (DeAngelo, 1981). Regarding this point, Raiborn, Schorg and Massoud (2006) point out that the lack of independence in the auditor-client relationship, the audit's purpose itself would be compromised, and the market would disregard the auditor's role, making it irrelevant. Very recently, corporate scandals, involving companies such as Enron, have shown that problems affecting auditor independence can lead to loss of reputation and, in turn, to complete loss of market share, and even bankruptcy of large audit firms like Arthur Andersen - until then considered one of the five largest in the world- in addition to major losses to a country's economy.

Among the solutions found by regulators to enhance auditor independence is mandatory rotation of audit firms or audit partners. Mandatory rotation of external audit firms aims to guarantee auditor independence, thus reducing client pressure in long-term relationships. According to the Securities and Exchange Commission (SEC, 2003), mandatory rotation of auditors would bring a "fresh look" to financial statements, enhancing audit independence and, as a consequence, the quality of services provided to clients. In empirical terms, surveys by Jennings, Pany and Reckers (2006), Daniels and Booker (2011) and Dopuch, King and Schwartz (2001) have shown positive effects due to enhanced auditor independence with the adoption of mandatory rotation of audit firms.

Although clients have a positive view of mandatory rotation due to auditor independence considerations, when it comes to the relationship between auditor tenure and the quality of accounting information, the evidence points to another direction. Research by DeFond and Zhang (2014) and Casterella and Johnston (2013) indicate a positive association of between auditor tenure and higher earnings quality, as measured by accrual earnings management and other criteria like accounting conservatism. Many of these studies attributes this result to expertise gains from the audit work, in a relationship in which the auditor or the firm tenure is longer.
This logic, however, must be viewed with care, as the study by Chi, Lisic and Pevzner (2011) indicated that longer auditor tenure would be associated with greater real earnings management. The authors attribute their findings to a trade-off between accrual management and real earnings management. According to Chi et al. (2011), managers engage in more extensive real earnings management when pressured by long relationships with independent auditors. This generally impairs the quality of financial information and may even compromise the company's aggregated operating performance in the long run, as earnings management by real activities causes greater long-term effects than by accruals.

The decision-making process of investors and creditors (the main focus of external audit services) basically involves two main decisions: how to allocate capital among investment opportunities; and whether to maintain or not such investments (Healy \& Palepu, 2001). In this sense, the investor or creditor should have access to adequate, quality information in order to assess different opportunities and choose according to one's risk propensity. Based on this logic, comparability is considered an important qualitative characteristic, as mentioned by Simmons (1967), by enhancing the usefulness of accounting information for external users.

Comparability is a measure of information quality that is at the heart of investment decisions and plays a key role in information environment quality, influencing the allocation of capital between countries (DeFond, Hu, Hung \& Li, 2011; Fang, Maffett \& Zhang, 2015; Yip \& Young, 2012), market liquidity (Barth, Landsman, Lang \& Williams, 2013), the quality of analysts' forecasts (DeFranco, Kothari \& Verdi, 2011), the protection of minority shareholders (Kim , Kraft \& Ryan, 2013) and the protection of lenders in loan contracting (Fang, Li, Xin and Zhang, 2012).

The comparability measures used in our study were: the similarity of the accounting function used by DeFranco et al. (2011) and an adaptation of the measure used by Ribeiro (2014) in his research. According to the conceptual framework of the International Financial Reporting Standards (IFRS, 2018), comparability is the qualitative characteristic of the information that enables users to identify similarities in and differences among financial statements for two different companies and for the same company from period to period. In a practical way, comparability is built through the accounting process 
of recognition, measurement and disclosure. For two companies that present the same economic event, the use of the same accounting process is expected in order to achieve comparability.

The rotation of firm or audit partner, or their tenure, can impact this process, as their reports can significantly change the way managers interpret economic events. Audit firm or partner rotation can influence comparability in a positive or negative way. The downside is a possible disruption to some procedure or a different bias on the part of the new firm (or auditor) regarding some established accounting procedure, thus demanding a new interpretation. This can affect the accounting process and the way in which managers map their business in accounting terms. For example, the new auditor, for fear of litigation, may question an established policy which classifies a certain provision as possible, requiring it to be classified as probable. This would affect the accounting profit for the year without necessarily entailing any changes to the economic basis in the view of business managers. Changes like this in the interpretation can be detrimental to comparability. The upside is the new auditor or firm, in view of the need to carry out a more in-depth mapping to get to know the business - also due to a greater litigation risk according to DeFond and Zhang (2014) - can motivate managers to adopt a more conservative behavior and inhibit accrual earnings management practices, which should enhance comparability in the short term.

Although there are several studies addressing the effect of auditor rotation (firms and partners) on financial information quality - DeFond \& Zhang (2014) and Casterella \& Johnston (2013) provide an extensive list of studies on the topic - none of them dealt directly with financial statement comparability. The studies that get closer to the topic were those by Li, Qi and Zhang (2017), who analyzed the effect of two companies employing the same audit firm on comparability; Francis, Pinnuck and Watanabe (2014), who tested the effect of the audit carried out by two of the four largest audit firms (Big 4) on comparability; and Zhang (2018) who analyzed how comparability impacts audit risk, since the advantages or disadvantages of auditor rotation are not yet empirically consolidated in the literature (DeFond \& Zhang, 2014) and the Public Company Accounting Oversight Board is currently discussing the imposition of mandatory audit firm rotation in the United States, which could affect many companies around the world listed in the US market. This study, thus, aims to analyze the effect of rotation and tenure of audit firms and partners on the comparability and consistency of financial statements.

Publicly-held companies in Brazil were chosen to serve as a background to our discussion, since the country has imposed mandatory audit firm rotation since the issuance of instruction n. 308/1999 of the Brazilian Securities Commission (CVM, 1999), that is, listed companies are already completely adapted to the process. In addition, the country established in 2008 an exception to the mandatory rotation with CVM decision n. 549 due to Brazil's adoption of the international standard. This allowed us to examine both voluntary and mandatory auditor and firm rotation and made the country an ideal study scenario, considering that few other countries present the same regulatory conditions.

Our results show that mandatory audit firm rotation, voluntary audit firm rotation or audit partner rotation do not affect the comparability and consistency of financial statements. On the other hand, our findings also indicate that audit firm tenure of up to three years positively influences both the comparability and the consistency of financial statements. These findings are in agreement with the evidence presented by DeFond and Subramanyam (1998), which identified a preference for more conservative accounting choices by the auditor in the case of auditor rotation due to the greater litigation risk, and with Chi et al. (2011), whose results suggest a trade-off between real activities manipulation and accrual manipulation by managers in long-term auditor-client relationships. This relationship impairs comparability and consistency, as real earnings are managed but the accounting policies remain the same and do not capture this.

This study aims to contribute to the discussion on the need for audit firms and partners to rotate the auditor within up to five years, as established by law, in the same way that it aims to contribute to the discussion on the rotation being carried out in less than five years, as audit firm and partner rotation do not impair comparability and consistency of financial statements. The suggestion for companies to avoid long-term relationships with auditors is also due to results that suggest the association of greater comparability and consistency with audit firm tenure of up to three years. Thus, we understand that the positive effects of auditor rotation such as enhanced independence from the client outweigh other positive effects, such as expertise gains from longer tenure in terms of comparability and consistency of financial statements in the analyzed environment. 


\section{OTHER RELATED STUDIES}

Auditor rotation is a subject that has been approached in several ways. Among the main and most consolidated approaches are: (i) the investigation of the effects of audit firm and partner mandatory rotation or tenure on audit quality (Daniels \& Booker, 2011; Kwon, Lim \& Simnett, 2014; Lowensohn, Reck, Casterella \& Lewis, 2007; Myers, Myers \& Omer, 2003; Nagy, 2005); (ii) the analysis of the dynamics of auditor and audit firm rotation and their independence from the client company (Arel, Brody \& Pany, 2006; Dopuch et al., 2001; Jennings et al., 2006; Kaplan \& Mauldin, 2008; Wang \& Tuttle, 2009); and (iii) the relationship between quality of financial information and auditor or audit firm rotation and tenure (Chen, Lin \& Lin 2008; Chi et al., 2011; Davis, Soo \& Trompeter, 2009; Ghosh \& Moon, 2005; Jenkins \& Valury, 2008; Johnson, Khurana \& Reynolds, 2002; Li, 2010; Myers et al., 2003).

These studies' findings are generally conflicting and do not unanimously support the need for mandatory rotation, especially with regard to financial information quality and audit firm and auditor tenure. Johnson et al. (2002), for example, using 10 years of data for US companies, found that longer tenures do not affect the quality of financial reports, as measured by accruals that can be managed and by the persistence of earnings. The authors examined audit firm tenure by year, and also considered short ( 2 to 3 years), medium ( 4 to 8 years) and long (over 9 years) tenures in their model. Their results showed that the two quality measures are higher for medium tenures compared with short tenures, but for long tenures there were no significant differences, that is, for very short-term relationships, earnings quality tends to decrease compared with longer relationships. However, very long auditor-client relationships also do not increase earnings quality compared with medium tenures.

In the same vein, Myers et al. (2003) also found similar results. However, the authors used earnings management as calculated by the Jones model and absolute current accruals as a measure of earnings quality. The results obtained by the authors suggest that longer auditor tenure places greater constraints on extreme management practices and, thus, decrease the use of discretionary accruals, especially at the ends of the distribution. Ghosh and Moon (2005), in turn, applied a questionnaire to investors and concluded that they do not perceive extended tenure as affecting earnings quality.
Chen et al. (2008) tested the relationship between tenure and earnings quality, using as a proxy absolute discretionary accruals in Thailand. The authors concluded that, after controlling for audit partner rotation, longer audit partner-client relationships do not decrease earnings quality; on the contrary, they increase earnings quality in financial reports. Davis et al. (2009) also used accrual earnings management to examine the relationship between quality and tenure and controlled for the pre- and postSOX periods in US companies. Their results show that in the pre-SOX period there is an increase in earnings management with longer audit partner tenure. However, after the enactment of SOX, even with an increase in audit partner tenure, there was a decline in earnings management.

Contrary to these results, the study by Li (2010) showed a positive association between audit partner tenure and accounting conservatism for large firms that are strongly monitored, but a negative one for small, weakly monitored companies. Chi et al., (2011), in turn, found a positive association between audit partner tenure and real earnings management, in addition to a negative association between audit partner tenure and accrual earnings management. According to the authors, this finding demonstrates that, when unable to manage earnings by accruals, managers resort to real earnings management. It is worth mentioning that this situation can become a problem for users of financial information, because real earnings management generally has more long-term effects than accruals manipulation and can affect the firm's operational performance.

Although studies on quality versus tenure can affect comparability (as it is a measure of quality of information), three studies stand out from the others for directly analyzing this qualitative characteristic. The first study was carried out by Francis et al. (2014), whose aim was to analyze how the size of audit firms (Big 4) affected the comparability of financial reports. More specifically, the authors sought to analyze whether a pair of companies being audited by firms of the same size leads to enhanced comparability of their financial reports. When the pair of companies is audited by one of the four largest firms (Big 4) - that is, EY, Deloitte, PWC and KPMG - the comparability of their financial statements increases compared with pairs of companies audited by firms of different sizes. As a measure of comparability, the authors used earnings covariation and a measure of closeness of 
accruals. The authors concluded that the size of the audit firm can direct the way in which the client interprets its economic reality.

The second study that analyzed the direct association between audit and comparability was carried out by $\mathrm{Li}$ et al. (2017). The research objective of Li et al. (2017), as in the study by Francis et al. (2014), was to assess the comparability of two companies audited by the same audit partner. The comparability measures used were the same as in the previous study by Francis et al. (2014), that is, earnings covariation and closeness of accruals. The results of Li et al. (2017) also showed improved comparability for clients audited by the same audit partner compared with clients audited by different partners, including within the same audit firm. The research by Li et al. (2017) reinforces the understanding that, even within audit firms with an institutionalized opinion, partners can make a difference in how clients recognize and measure their economic events.

Finally, the third study was carried out by Zhang (2018). The author inverted the logic of the other researches and investigated how comparability, measured by the similarity of the accounting function of DeFranco et al. (2011), can influence the audit risk and the efficiency of the auditor's work. Zhang (2018) found, in a sample of US companies, that comparability is associated with a lower likelihood of auditor opinion error, as well as with less effort by the auditor (measured by amount charged and delay) expended on the audit. Zhang (2018) concluded that comparability is a relevant characteristic for measuring audit risk.

These three studies directly related to our research show us that comparability presented a significant association with audit firm size, with the same audit partner engaged in the audit of two clients and that it can influence the audit risk, in addition to the planning of the audit partner work (Francis et al., 2014; Li et al., 2017; Zhang, 2018). Although these three studies have reached relevant conclusions, none of them had the same scope as our study. The studies that adopted an approach closer to ours (although they examined audit firm size or audit partners and not rotation as we did) used a different measure of comparability.

Both Francis et al. (2014) as Li et al. (2017) used earnings covariation as a measure of comparability. This measure, according to Ribeiro, Carmo, Fávero and Carvalho (2016a), is more suitable to assess uniformity than comparability and presents an underlying rationale very different from the original measure by DeFranco et al. (2011), which was used in our study. The only investigation that used the same measure of comparability of our study was that by Zhang (2018), which has a different aim, however. In the study by Zhang (2018), the metric used by DeFranco et al. (2011) was an independent variable used to test how it impacted the audit risk and the planning of the audit partners' work. In our study, it will be the dependent variable and we will examine what will be the effect of audit firm and audit partner rotation on this measure.

\section{METHODS}

The study population comprises all companies listed on Brasil, Bolsa, Balcão (B3) between 2010 and 2018. This period was chosen due to the adoption of international accounting standards (that is, IFRS) in Brazil. The initial sample is composed of all companies for which there was information available during the analysis period, totaling 211 companies, classified by sector of economic activity.

The Level 3 of the North American Classification System (NAICS) was used to classify the companies' sectors of economic activity. Level 3 of NAICS is the most analytical and enables a better grouping of companies within their subactivities. This grouping is necessary because the economic events occurring within each sector must be as similar as possible, considering that comparisons require specific parameters. The sector classification found 79 sectors that could be analyzed. Of these, we chose to use sectors that had at least 4 companies that could be compared. As the sector is a variable that needs to be controlled in the comparability model (Ribeiro, 2014), using sectors with too few companies would affect the degrees of freedom of the model without ensuring an adequate variability to the measure of comparability.

As in the study by Francis et al. (2014), firms in the Management of Companies sector (holding companies) were not considered, because they manage other organizations in different activities and, generally, cannot be compared on the same basis. As in the study by Ribeiro, Carmo, Fávero and Carvalho (2016b), companies operating with currencies other than the real (Embraer) were not considered. In addition, companies in the banking sector (12 companies) were not selected for the final sample, as they differ from companies in other sectors in terms of standards (in their case, established by the 
Central Bank of Brazil). Thus, the sample was composed of 50 companies from 7 different sectors.

To measure comparability, we used the accounting function similarity model developed by DeFranco et al. (2011). The reasoning behind the comparability measurement is presented in Appendix A. The second measurement used, on the other hand, involves comparability over time. For this measurement, we gave the name of consistency, to differentiate it from the measurement used in the study by DeFranco et al. (2011). This measurement was originally adapted by Ribeiro in his thesis (2014) and its calculation is presented in Appendix B.

Regarding the period of analysis, to calculate comparability and consistency, the 2010-2018 period was considered, as this was when the IFRS was fully implemented in Brazil. The information needed to calculate these variables was collected using the Economatica ${ }^{\circ}$ database. The year 2012 was chosen as starting point, since measuring comparability and consistency requires data referring to the previous 11 quarters and the current quarter for each company. As for the collection of data on audit firm and partner rotation and tenure, we used the external auditor reports available on CVM's website. It is worth mentioning that, to measure audit partner and firm tenure, data was collected for audit firms and partners since the beginning of their relationship with the client, that is, in some cases, the period analyzed for this variable includes years prior to the 2012-2018 cutoff period. Table 1 shows the dependent and independent variables used in the multivariate models.

Table 1

Dependent and independent variables used in the model

\begin{tabular}{cccc}
\hline & Dependent variables & References \\
\hline $\begin{array}{c}\text { Variable } \\
\text { (COMPM) }\end{array}$ & $\begin{array}{c}\text { Description } \\
\text { on pairs in the sector }\end{array}$ & $\mathrm{ROA}_{\mathrm{it}}=\alpha_{\mathrm{i}}+\beta_{\mathrm{i}}$ Return $_{\mathrm{it}}+\varepsilon_{\mathrm{it}}$ & DeFranco et al. (2011) \\
\hline Consistency (CONSIS) & Mean individual consistency & $\mathrm{ROA}_{\mathrm{it}}=\alpha_{\mathrm{i}}+\beta_{\mathrm{i}}$ Return $_{\mathrm{it}-1}+\varepsilon_{\mathrm{it}-1}$ & Ribeiro (2014) \\
\hline Variable & Independent variables & References \\
\hline
\end{tabular}

Mandatory rotation (MANDATORY)

Dichotomous variable measuring whether audit firm rotation occurred up to or after five years since the last audit firm rotation
Dummy variable with two categories:

(1) mandatory rotation, (0) no rotation or voluntary rotation of the audit firm
Kim, Lee and Lee. (2015) and Silvestre, Costa and Kronbauer (2018)
Voluntary rotation (VOLUN)
Dichotomous measuring whether independent audit firm rotation occurred up to five years since the last audit firm rotation
Dummy variable with two categories:

(1) voluntary rotation, (0) no rotation or mandatory rotation of audit firm
Kim et al. (2015) and Silvestre et al. (2018)

\section{Audit partner rotation (PARTROTATION)}

Dichotomous variable measuring whether the company was audited by a different audit partner from the previous year
Dummy variable with two categories:

(1) rotation or (0) no rotation of audit partner

Jenkins and Vellury (2008)

Dummy variable with two categories:

(1) change or no change (0) to audit

firm size, considering size as Big 4 or not Big 4
Li (2010), Lawrence, Minutti-Meza and Zhang (2011) and Francis et al (2014)

\section{(SIZEROTATION)}

Dichotomous variable measuring whether the audit firm is the same two sizes, Big 4 or not Big 4
Dichotomous variable measuring whether the audit firm's tenure is short (1 to 3 years)
Dummy variable with two categories:

(1) tenure of 1 to 3 years, (0) tenure longer than 3 years
Johnson et al. (2002), Harris and Whisenant (2012) and Bell, Causholli and Knechel (2015) 


\begin{tabular}{|c|c|c|c|}
\hline \multicolumn{4}{|c|}{ Independent variables } \\
\hline Variable & Description & Operation & References \\
\hline $\begin{array}{l}\text { Short audit } \\
\text { partner tenure } \\
\text { (STENPARTNER) }\end{array}$ & $\begin{array}{l}\text { Dichotomous variable measuring } \\
\text { whether audit partner tenure is short } \\
\text { ( } 1 \text { to } 3 \text { years) }\end{array}$ & $\begin{array}{c}\text { Dummy variable with two categories: } \\
\text { (1) tenure of } 1 \text { to } 3 \text { years, }(0) \text { tenure } \\
\text { longer than } 3 \text { years }\end{array}$ & $\begin{array}{c}\text { Johnson et al. (2002), Chi et al. } \\
\text { (2011) and Garcia-Blandon and } \\
\text { Argiles Bosch (2017) }\end{array}$ \\
\hline Market-to-book (MB) & $\begin{array}{l}\text { Variable measuring business growth } \\
\text { expectation for the market }\end{array}$ & Market value / Book equity & $\begin{array}{l}\text { Lee, Li and Yue (2006), Mcvay, } \\
\text { Nagar and Tang (2006), Ribeiro et al. } \\
\text { (2016a) and Ribeiro et al. (2016b) }\end{array}$ \\
\hline $\begin{array}{l}\text { Degree of operating } \\
\text { leverage (DOL) }\end{array}$ & $\begin{array}{l}\text { Measurement of operational } \\
\text { performance and the company's cost } \\
\text { structure }\end{array}$ & $\begin{array}{l}\text { Gross Profit / (Gross Profit - Selling } \\
\text { and Administrative Expenses) }\end{array}$ & $\begin{array}{c}\text { Sohn (2016), Francis, Hanna and } \\
\text { Vincent (1996), Ribeiro et al. (2016a) } \\
\text { and Ribeiro et al. (2016b) }\end{array}$ \\
\hline $\begin{array}{l}\text { Size } \\
\text { (SIZE) }\end{array}$ & $\begin{array}{c}\text { Logarithm of the company's total } \\
\text { assets }\end{array}$ & Napierian logarithm of total assets & $\begin{array}{l}\text { Watts and Zimmerman (1986), } \\
\text { Doyle, Ge and McVay (2007), } \\
\text { Ribeiro et al. (2016a) and Ribeiro et } \\
\text { al. (2016b) }\end{array}$ \\
\hline $\begin{array}{l}\text { Economic crisis } \\
\quad(\text { CRISIS) }\end{array}$ & $\begin{array}{l}\text { Variable measuring whether annual } \\
\text { variation in Gross Domestic Product } \\
(\mathrm{GDP}) \text { is negative }\end{array}$ & $\begin{array}{c}\text { Dummy variable with two categories: } \\
\text { (1) negative variation in GDP, }(0) \\
\text { positive variation in GDP. }\end{array}$ & Cohen and Zarowin (2007) \\
\hline Sector & Level 3 NAICS & $\begin{array}{l}\text { Dummy variable representing } \\
\text { each company's economic sector: } \\
\text { (0) Construction, (1) Electricity, } \\
\text { (2) Telecommunications, (3) } \\
\text { Slaughterhouses, (4) Auto parts, (5) } \\
\text { Rental companies and (6) Other } \\
\text { industries. }\end{array}$ & $\begin{array}{l}\text { Verrecchia and Weber (2006) and } \\
\text { Bagnoli and Watts (2010) }\end{array}$ \\
\hline
\end{tabular}

Source: Elaborated by the authors.

The variables of interest in our study are the mandatory and voluntary rotation, in addition to the short tenure of the audit partner and firm. As for the audit partner tenure and audit firm tenure variables, none of the sample companies' audit partner tenures exceeded 5 years and none of the audit firm tenures exceeded 8 years. As in the study by Johnson et al. (2002), audit partner tenure and the audit firm tenure were only of medium term (4 to 8 years), and no long-term cases (over 9 years) were found. Thus, only one dichotomous variable was used for audit partner (TENCSOCIO) and for audit firm (TENCFIRMA), since the audit partner and audit firm tenures analyzed in this study are short or medium.

In addition, control variables were used as in the studies by Zhang (2018), Ribeiro (2014), Ribeiro et al. (2016a) and Ribeiro et al. (2016b). According to these authors, the measure of comparability has a significant relationship with market-to-book ratio (MB), degree of operational leverage (GAO), size of the company (TAM), sector of economic activity of the company and the size of the audit firms is rotated. An economic crisis variable (CRISIS) was also used, given that the results showed a reduction in comparability, especially in periods of negative GDP variation.

Regarding the sample treatment, the total possible number of observations is 350 , of which 39 refer to observations with insufficient data. The sample was thus composed of 311 observations. In addition, the data treatment included a multivariate outlier analysis. We opted for the technique developed by Hadi (1992) 
and detected 51 outliers, which were excluded from the sample. Therefore, the final sample was composed of 260 observations.

The panel data model can be classified as short (there are more observations than analyzed periods) and unbalanced (there are missing observations over time). To determine the most appropriate estimation according to the data characteristics, the Breusch-Pagan (BP) test was performed on the four multivariate models. The BP test results for the multivariate models of the impact of the audit firm and the audit partner on comparability (Model 1 and Model 2) suggests the use of the pooled ordinary least square (POLS) technique. The BP test indicated that is a random effects estimation model is the most suitable for the multivariate models of the impact of the audit firm and partner on consistency (Model 3 and Model 4) - it is worth noting that the fixed effects model was not considered, because the multivariate analyzes were controlled for sector.

To satisfy the assumptions of the multivariate models, Pearson's correlation test was performed, as well as the Variance Inflation Factor (VIF) test. These tests showed that none of the independent variables presented a correlation above 0.70 , and also that all VIF test results remained below 5 . With these results, as suggested by Fávero and Belfiore (2017), none of the multivariate models are susceptible to the problem of multicollinearity. In addition, all multivariate models were clustered in individuals so that the results would not be susceptible to problems related to the heteroskedasticity of the data, as well as to serial autocorrelation.

\section{PRESENTATION AND ANALYSIS OF RESULTS}

Table 2 presents the descriptive statistics for the quantitative variables.

Table 2

Descriptive statistics for the quantitative variables

\begin{tabular}{|c|c|c|c|c|c|c|c|}
\hline \multirow{2}{*}{ Variables } & \multirow{2}{*}{ Mean } & \multicolumn{3}{|c|}{ Standard Deviation } & \multirow{2}{*}{ Minimum } & \multirow{2}{*}{ Maximum } & \multirow{2}{*}{$\begin{array}{l}\text { Number of } \\
\text { Observations }\end{array}$} \\
\hline & & Overall & Between & Whithin & & & \\
\hline СОМРM & -4.245 & 2.401 & 1.719 & 1.664 & -10.969 & -0.057 & 260 \\
\hline CONSIS & -0.874 & 0.866 & 0.553 & 0.701 & -4.711 & -0.118 & 260 \\
\hline $\mathrm{MB}$ & 1.379 & 0.994 & 1.031 & 0.489 & 0.041 & 5.496 & 260 \\
\hline DOL & 1.002 & 1.571 & 1.273 & 0.940 & -3.205 & 7.436 & 260 \\
\hline SIZE & 15.592 & 1.137 & 1.150 & 0.207 & 13.301 & 18.702 & 260 \\
\hline
\end{tabular}

Source: Elaborated by the authors.

The analysis of the audit firm and the audit partner tenures showed that the mean audit partner tenure is 2 years and 1 month, less than for the mean audit firm tenure, which is 2 years and 6 months. This is interesting because it demonstrates that the rotation usually takes place before the mandatory deadline. This suggests that, on average, the tenure of both the audit partner and the audit firm is short. This understanding is valid, since for $73.74 \%$ of the observations the audit firm tenure is short and for $83.84 \%$ of the observations the audit partner tenure is also short, which goes against the pro-regulation argument defending mandatory rotation every 5 years. It should be noted that the mean audit partner tenure we found differs from that found by Chi et al. (2011) and Chen et al. (2008). In these studies, the audit partner tenure averaged about 13 years and 8 years and 4 months, respectively. An explanation for this is that in Brazil the mandatory rotation has already been in force for more than a decade, that is, it is a consolidated non-market mechanism and companies are already adapted to it. Another explanation may be the high turnover of audit firm partners and the low degree of specialization of auditors due to the short-term relationship established by mandatory rotation. All this points out that auditor tenure in Brazil should be classified as short, considering the study by Casterella and Johnston (2013).

The measurement of comparability, on the other hand, showed a -4.24 mean. This is considerably less than the results of other similar studies, such as those by DeFranco et al. (2011), Sohn (2016), Fang et al. (2012) and Ribeiro 
et al. (2016b), which found $-2.70,-1.90,-2.03$ and -2.63 as mean comparability values, respectively. A viable explanation for this finding is the economic slowdown the country experimented as of the second quarter of 2014.

An analysis over the years shows a decrease in the comparability of companies, with this qualitative characteristic averaging -3.10 in 2012 and -3.33 in 2013. The Student T test, at 5\%, showed that there was no significant difference in the mean comparability value between these two years. For 2014, the mean comparability value reached -4.15 , and even so there was no significant difference with the previous year. For 2015 , however, the mean comparability value was -4.68 , presenting a significant difference (at the level of 5\%) with the mean comparability for the previous year, that is, 2014. This behavior of significant decrease in the mean comparability value persisted in 2016 , for which this qualitative characteristic presented -6.00 as the mean. For 2017 , the mean comparability was -5.46 , a result that is not significantly different from the mean value of comparability for 2016. For 2018, the mean comparability was -3.21 , a significant increase in the mean value (at the level of 5\%) of this qualitative characteristic compared with the mean for the previous year.

The mean value of consistency was -0.87 , similar to the result found by Ribeiro (2014). Unlike comparability, consistency did not show a marked decrease when considering the analyzed period. The Wilcoxon test, at the $5 \%$ level, identified no significant difference in the level of consistency of the companies' financial reports in relation to the previous year. The mean for this variable was $-0.78,-0.81$ and -0.78 for 2012,2013 and 2014, respectively. In the years when the GDP variation was negative, the consistency was similar to the previous periods, with -0.98 and -0.93 as the means for 2015 and 2016, respectively. For 2017, consistency averaged -1.07; and for 2018 the mean was -0.74 , with no significant difference between these years. The results of the comparability and consistency measurements, by annual period, are shown in Figure 1.
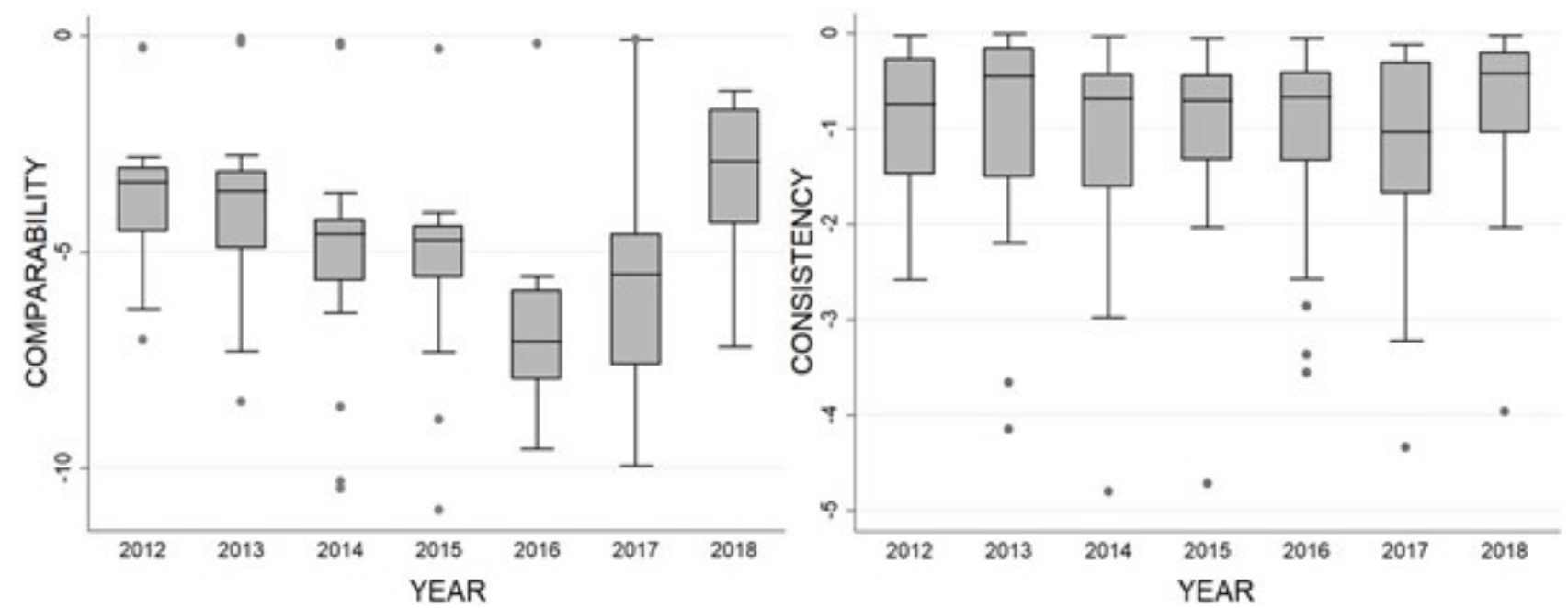

Figure 1 Behavior of comparability and consistency from 2012 to 2017

Source: Elaborated by the authors.

Next, we analyzed the panel data regression models for the investigated measures. To avoid overlapping periods, the rotation of audit firms and partners were separated into two different models, as well as their respective type of tenure (short tenure and medium tenure). This procedure was necessary because in almost every audit firm rotation the partner responsible for the audit service was also substituted, which means that the periods between the rotation of the audit firm and the rotation of the audit partner would overlap and their effect would not be adequately captured. Table 3 shows the results for the factors related to the measurement of comparability and consistency. 
Table 3

Multivariate model of the comparability and consistency measurement

\begin{tabular}{|c|c|c|c|c|c|c|c|c|}
\hline \multirow{4}{*}{ Independent variables } & \multicolumn{4}{|c|}{ Comparability } & \multicolumn{4}{|c|}{ Consistency } \\
\hline & \multicolumn{2}{|c|}{ Model 1} & \multicolumn{2}{|c|}{ Model 2} & \multicolumn{2}{|c|}{ Model 3} & \multicolumn{2}{|c|}{ Model 4} \\
\hline & \multicolumn{2}{|c|}{ Audit firm } & \multicolumn{2}{|c|}{ Audit partner } & \multicolumn{2}{|c|}{ Audit firm } & \multicolumn{2}{|c|}{ Audit partner } \\
\hline & Coef. & t-stat & Coef. & t-stat & Coef. & t-stat & Coef. & t-stat \\
\hline MANDATORY & -0.498 & -1.82 & & & -0.165 & -1.61 & & \\
\hline VOLUN & -0.157 & -0.39 & & & -0.188 & -0.90 & & \\
\hline STENFIRM & 0.691 & $2.26^{* *}$ & & & 0.348 & $2.04^{*}$ & & \\
\hline PARTROTATION & & & -0.227 & -1.17 & & & -0.014 & -0.13 \\
\hline STENPARTNER & & & 0.666 & 1.65 & & & 0.189 & 1.00 \\
\hline SIZEROTATION & 0.099 & 0.19 & 0.131 & 0.27 & -0.550 & -1.47 & -0.639 & -1.93 \\
\hline$M B$ & 0.041 & 0.35 & 0.446 & 0.40 & 0.088 & 1.31 & 0.081 & 1.02 \\
\hline DOL & 0.172 & 1.75 & 0.175 & 1.70 & 0.103 & $2.98^{* *}$ & 0.112 & $3.27^{* *}$ \\
\hline SIZE & -0.219 & -1.88 & -0.224 & -1.77 & -0.111 & -1.43 & -0.085 & -1.00 \\
\hline CRISIS & -0.973 & $-3.54^{* *}$ & -1.063 & $-4.28^{* *}$ & 0.601 & 0.45 & -0.053 & -0.43 \\
\hline Constant & -2.623 & -1.36 & -2.601 & -1.23 & 0.337 & 0.28 & 0.046 & 0.03 \\
\hline Sector control & \multicolumn{2}{|c|}{ Yes } & \multicolumn{2}{|c|}{ Yes } & \multicolumn{2}{|c|}{ Yes } & \multicolumn{2}{|c|}{ Yes } \\
\hline $\mathrm{R}^{2}$ & \multicolumn{2}{|c|}{0.5011} & \multicolumn{2}{|c|}{0.4963} & \multicolumn{2}{|c|}{0.2042} & \multicolumn{2}{|c|}{0.1756} \\
\hline F-statistic/Wald & \multicolumn{2}{|c|}{$56.31^{* *}$} & \multicolumn{2}{|c|}{$44.30^{* *}$} & \multicolumn{2}{|c|}{$64.84^{* *}$} & \multicolumn{2}{|c|}{$44.15^{* *}$} \\
\hline Observations & \multicolumn{2}{|c|}{260} & \multicolumn{2}{|c|}{260} & \multicolumn{2}{|c|}{260} & \multicolumn{2}{|c|}{260} \\
\hline
\end{tabular}

Note: * significance level at 5\%; ** significance level at 1\%. The multivariate regressions for Model 1 and Model 2 were estimated using OLS with robust standard errors clustered in individuals. The multivariate regressions for Model 3 and 4 were estimated using GLS (random effects) with robust standard errors clustered in individuals. The constant for all complete models absorbed the reference categories ( 0 ) for all dichotomous variables, with the variable: SECTOR = CONSTRUCTION. The models were obtained using the following equations:

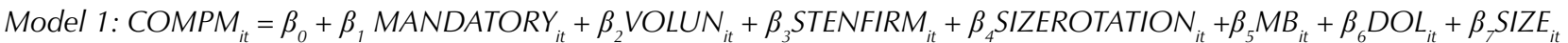
$+\beta_{8}$ CRISIS $_{i t}+\beta_{9}$ ELECTRICITY $_{i t}+\beta_{10}$ TELECOMMUNICATIONS $_{i t}+\beta_{11}$ SLAUGHTERHOUSES $_{i t}+\beta_{12}^{i t}$ AUTOPARTS $_{i t}+\beta_{13}^{\text {it }}$ RENTAL $_{i t}+$ $\beta_{14}$ OTHERSINDUSTRIES ${ }_{i t}+\varepsilon_{i t}$

Model 2: COMPM $_{i t}=\beta_{0}+\beta_{1}$ PARTROTATION $_{i t}+\beta_{2}$ STENPARTNER $_{i t}+\beta_{3}$ SIZEROTATION $_{i t}+\beta_{4} M_{i t}+\beta_{5}$ DOL $_{i t}+\beta_{6}$ SIZE $_{i t}+\beta_{7}$ CRISIS $_{i t}$ $+\beta_{8}$ ELECTRICITY $_{i t}+\beta_{9}$ TELECOM $_{i t}+\beta_{10}$ SLAUGHTERHOUSES $_{i t}+\beta_{11}$ AUTOPARTS $_{i t}+\beta_{12}$ RENTAL $_{i t}+\beta_{13}$ OTHERSINDUSTRIES $_{i t}+\varepsilon_{i t}$ Model 3: CONSIS $i t=\beta_{0}+\beta_{1}$ MANDATORY $_{i t}+\beta_{2}$ VOLUN $_{i t}+\beta_{3}$ STENFIRM $_{i t}+\beta_{4}$ SIZEROTATION $_{i t}+\beta_{5}$ MB $_{i t}+\beta_{6} D O L_{i t}+\beta_{7}$ SIZE $_{i t}+$ $\beta_{8}$ CRISIS $_{i t}+\beta_{9}$ ELECTRICITY $_{i t}+\beta_{10}$ TELECOMMUNICATIONS $_{i t}+\beta_{11}$ SLAUGHTERHOUSES $_{i t}+\beta_{12}$ AUTOPARTS $_{i t}+\beta_{13}$ RENTAL $_{i t}+$ $\beta_{14}$ OTHERSINDUSTRIES $i t+\varepsilon_{i t}$

Model 4: CONSIS $_{i t}=\beta_{0}+\beta_{1}$ PARTROTATION $_{i t}+\beta_{2}$ STENPARTNER $_{i t}+\beta_{3}$ SIZEROTATION $_{i t}+\beta_{4} M_{i t}+\beta_{5}$ DOL $_{i t}+\beta_{6}$ SIZE $_{i t}+\beta_{7}$ CRISIS $_{i t}$ $+\beta_{8}$ ELECTRICITY $_{i t}+\beta_{9}$ TELECOM $_{i t}+\beta_{10}$ SLAUGHTERHOUSES $_{i t}+\beta_{11}$ AUTOPARTS $_{i t}+\beta_{12}$ RENTAL $_{i t}+\beta_{13}$ OTHERSINDUSTRIES $_{i t}+\varepsilon_{i t}$

Source: Elaborated by the authors.

The examination of Model 1, which concerns the effect of audit firm rotation, tenure and size on comparability, showed that mandatory audit firm rotation, due to the issuance of instruction n. 308 (CVM, 1999) and, subsequently, of resolution n. 549 (CVM, 2008), did not significantly influence the comparability of financial reports. Likewise, no impact on comparability measurements was found for the companies that voluntarily changed the audit firm. Thus, our findings showed that audit firm rotation did not influence comparability, contrary to the results of the study by Silvestre et al. (2018), which detected a reduction in the quality of accruals associated with audit firm rotation. Our results also differ from the findings by Kim et al. (2015), as the authors conclude that the improvement in accrual quality occurs only under mandatory rotation.

Also regarding Model 1, our results indicate that short audit firm tenure is associated with enhanced comparability compared with tenure of more than 3 years. It can be inferred, therefore, that extending the audit firmclient relationship is detrimental to the comparability of financial reports. This result differs, in general, from the 
literature on information quality and audit firm tenure, which shows a positive association between longer auditor tenure and earnings quality (Casterella \& Johnston, 2013). This divergence can be explained in part by referring to the study by Bell et al. (2015), which found an optimal curve between tenure and audit quality. According to the authors, a very long auditor-client relationship is detrimental to audit quality and may have an impact on information quality.

In our study, the mean audit firm tenure curve can be considered as relatively short, as it stays below 3 years. Because in Brazil companies change the audit firm even before the mandatory rotation term (which is 5 years), those that maintain their engagement with the audit firm have a tendency to adopt less conservative accounting practices. This is in agreement with the study by Cameran, Prencipe and Trombetta (2014), which examined the association between rotation and audit quality in Italy (which mandates audit firm rotation every 3 years) and found that the rotation improves the quality of financial reports due to a higher level of accounting conservatism in the last year of the audit firm tenure. This evidence may be related to the findings by DeFond and Subramanyam (1998), who attribute the increase in conservatism to higher litigation risk at the time of the audit firm rotation. As for the other variables, they were not significant, with the exception of the economic crisis variable.

Model 2 showed no significant effect of audit partner rotation on the comparability of financial reports. This finding differs from that by Jenkins and Vellury (2008), which examined the effect of audit partner rotation after the implementation of SOX. The authors found a negative association between the quality of accounting information and short (up to 3 years) and medium ( 3 to 5 years) tenure. A possible explanation for the difference in results can be explained by the difference in institutional environment between the two studies. While in Brazil the regulation has been in force for almost two decades, the study by Jenkins and Vellury (2008) was conducted in a recently implemented regulatory environment.

The evidence shows that both short and medium audit partner tenure do not differ significantly in comparability. This is contrary to the results by Chi et al. (2011), which found that there is a trade-off between accrual earnings management and real earnings management in long-term audit partner-client relationships. However, the authors examined long-term relationships of over 8 years and these were not found in our study.

It is worth mentioning as a supplementary analysis that, in both comparability models (Models 1 and 2), the economic crisis variable showed a negative association with this qualitative characteristic. This result shows that in periods of economic downturn there is a decrease in the quality of financial reports. This was also observed by Paulo and Mota (2019) in their study on accrual earnings management. According to these authors, in times of crisis, managers increase the level of discretionary accruals to manage earnings. This behavior can also be observed in the current crisis caused by the COVID-19 pandemic. Some Brazilian banks were much more conservative than others in managing their estimates of losses with credit operations, these differences in interpretation can be amplified in times of crisis and significantly affect the comparability of financial reports.

The analysis of financial report consistency (Models 3 and 4) showed no significant effect of rotation of audit firm (mandatory or voluntary) or audit partner. The only impact identified on consistency was from short audit firm tenure. As with comparability, Model 3 results showed a positive effect on consistency for relationships of up to 3 years compared with longer relationships.

With regard to audit partner rotation, we observed no association with the level of consistency of financial reports. Similarly, a short audit partner tenure does not differ from a medium audit partner tenure in terms of level of consistency. In this sense, it is clear that these aspects (rotation and tenure) of the audit partner-client relationship do not impact the consistency of financial reports. This may be related to the same procedures being used by different audit partners belonging to the same audit firm (Francis et al., 2014). Thus, even if an audit partner is substituted by another partner at the same firm, the same internal procedures will be applied during the audit engagement - it is worth noting that this may also be true for the audit partner tenure, with the same audit style being adopted by the newly engaged partner belonging to the same audit firm.

Finally, changing the size of the audit firm also showed no significant effect on the measures analyzed. This result is in disagreement with the findings by Francis et al. (2014), suggesting that, in Brazil, even non-Big 4 audit firms are aligned in terms of accounting practices, regardless of the relative size of the audit firms. 


\section{FINAL CONSIDERATIONS}

This study aimed to investigate the effect of audit firm and audit partner rotation and tenure on the comparability and consistency of financial reports. The study results indicate that both mandatory rotation and voluntary change of audit firms are not related to the level of comparability and consistency of financial reports. These findings contribute to the discussion on mandatory rotation, as they show that there is no sudden change in the interpretation of the accounting process even when there is a change of the agent that attest its authenticity.

Theoretically, this study contribute to the discussions addressed by Jenkins and Vellury (2008), Kim et al. (2015), Wolf, Tackett and Claypool (1999) and Defond and Francis (2005), as our results show that auditor rotation was not detrimental to the comparability and consistency of the information presented in financial statements. In addition, the study results also suggest that a short audit firm tenure is associated with higher levels of comparability and consistency of financial reports compared with a longer audit firm tenure, that is, longer than 3 years.

It is worth mentioning that these results have practical implications, since no impact of audit firm rotation on the comparability and consistency of financial reports was found, thus suggesting that mandatory audit firm rotation is effective. This is because there is no sudden change in the level of comparability and consistency of financial reports in the year that the rotation occurred, indicating that the previous audit firm did not lose its independence from the client. In addition, the results concerning the audit firm tenure can contribute to the discussion on the benefits of mandatory rotation, as they show that a short tenure is related to a higher level of comparability and consistency of financial reports. From this we understand that with longer audit firm tenure the comparability of financial reports decreases to the point of impairing the decision-making process of investors. This leads to the understanding that the mandatory rotation of audit firms may be necessary and beneficial for investors.

Nevertheless, our results suggest that the rotation of the audit partner is not associated with the comparability and consistency of financial reports. Although our results are in contrast with those by Myers et al. (2003), they indicate that the most relevant rotation is of the audit firm and not of the audit partner. This became clear because there was no significant difference in consistency and comparability measurements between short tenure and long tenure. These findings may add to the results of Johnson et al. (2002), who found that the quality of financial reports only has an impact at audit-firm level. This evidence can be of assistance to external users (regulators and investors), as well as to the client companies themselves, as it suggests that the audit procedures carried out by different audit partners from the same audit firm are similar in an institutional environment of mandatory rotation. In this regulatory environment, therefore, the audit firm-client relationship is more relevant than the audit partner-client relationship, especially concerning the negative effects of long tenure on financial reports.

This study was not without limitations and, as in the study by Ribeiro et al. (2016b), one of them is not having considered possible effects of policies on the overall results. Another limitation is the reduced number of observations, due to the size of the Brazilian capital market, compared with other studies on comparability conducted in other countries, such as that by DeFranco et al. (2011). We suggest, therefore, that future research should be carried out to investigate the effect of audit style, as well as the effects of earnings management and of the macroeconomic environment on the comparability and consistency of financial reports. 


\section{REFERENCES}

Arel, B., Brody, R., \& Pany, K. (2006). Findings on the effects of audit firm rotation on the audit process under varying strengths of corporate governance. Advances in Accounting, 22, 1-27.

Bagnoli, M., \& Watts, S. G. (2010). Oligopoly, disclosure, and earnings management. The Accounting Review, 85(4), 11911214.

Barth, M. E., Landsman, W. R., Lang, M. H., \& Williams, C. D. (2013). Effects on comparability and capital market benefits of voluntary adoption of IFRS by US firms: Insights from voluntary adoption of IFRS by non-US firms. Rock Center for Corporate Governance at Stanford University. Working Papers, (3074).

Bell, T. B., Causholli, M., \& Knechel, W. R. (2015). Audit firm tenure, non-audit services, and internal assessments of audit quality. Journal of Accounting Research, 53(3), 461509.

Cameran, M., Prencipe, A., \& Trombetta, M. (2014). Mandatory audit firm rotation and audit quality. European Accounting Review, 25(1), 35-58.

Casterella, J. R., \& Johnston, D. (2013). Can the academic literature contribute to the debate over mandatory audit firm rotation? Research in Accounting Regulation, 25(1), 108-116.

Chen, C. Y., Lin, C. J., \& Lin, Y. C. (2008). Audit partner tenure, audit firm tenure, and discretionary accruals: Does long auditor tenure impair earnings quality? Contemporary Accounting Research, 25(2), 415-445.

Chi, W., Lisic, L. L., \& Pevzner, M. (2011). Is enhanced audit quality associated with greater real earnings management? Accounting Horizons, 25(2), 315-335.

Cohen, D. A., \& Zarowin, P. (2007). Earnings management over the business cycle. Retrieved from https://citeseerx.ist.psu.edu/viewdoc/ download?doi=10.1.1.1060.381\&rep=rep1\&type=pdf

Comissão de Valores Mobiliários (CVM). (2008). Deliberação n. 549.

Comissão de Valores Mobiliários (CVM) (1999). Instrução n. 308. Com as alterações introduzidas pelas instruções CVM n. 509/2011, 545/2014 e 591/2017.

Daniels, B. W., \& Booker, Q. (2011). The effects of audit firm rotation on perceived auditor independence and audit quality. Research in Accounting Regulation, 23(1), 78-82.

Davis, L. R., Soo, B. S., \& Trompeter, G. M. (2009). Auditor tenure and the ability to meet or beat earnings forecasts. Contemporary Accounting Research, 26(2), 517-548.

DeAngelo, L. E. (1981). Auditor size and audit quality. Journal of Accounting and Economics, 3(3), 183-199.

DeFond, M. L., \& Francis, J. R. (2005). Audit research after sarbanes-oxley. Auditing: A Journal of Practice \& Theory, 24(s1), 5-30.

DeFond, M. L., \& Subramanyam, K. R. (1998). Auditor changes and discretionary accruals. Journal of Accounting and Economics, 25(1), 35-67.
DeFond, M. L., \& Zhang, J. (2014). A review of archival auditing research. Journal of Accounting and Economics, 58(2-3), 275326.

DeFond, M. L., Hu, X., Hung, M., \& Li, S. (2011). The impact of mandatory IFRS adoption on foreign mutual fund ownership: The role of comparability. Journal of Accounting and Economics, 51(3), 240-258.

DeFranco, G., Kothari, S. P., \& Verdi, R. S. (2011). The benefits of financial statement comparability. Journal of Accounting Research, 49(4), 895-931.

Dopuch, N., King, R. R., \& Schwartz, R. (2001). An experimental investigation of retention and rotation requirements. Journal of Accounting Research, 39(1), 93-117.

Doyle, J., Ge, W., \& McVay, S. (2007). Determinants of weaknesses in internal control over financial reporting. Journal of Accounting and Economics, 44(1-2), 193-223.

Fang, V. W., Maffett, M., \& Zhang, B. (2015). Foreign institutional ownership and the global convergence of financial reporting practices. Journal of Accounting Research, 53(3), 593-631.

Fang, X., Li, Y., Xin, B., \& Zhang, W. J. (2012). Accounting comparability and loan contracting. Working Paper.

Fávero, L. P., \& Belfiore, P. (2017). Manual de análise de dados: estatística e modelagem multivariada com Excel $^{\circ}, S^{\circ} S S^{\circledR} e$ Stata ${ }^{\circledR}$. Rio de Janeiro, RJ: Elsevier.

Francis, J. R., Hanna, J. D., \& Vincent, L. (1996). Causes and effects of discretionary asset write-offs. Journal of Accounting Research, 34, 117-134.

Francis, J. R., Pinnuck, M. L., \& Watanabe, O. (2014). Auditor style and financial statement comparability. The Accounting Review, 89(2), 605-633.

Garcia-Blandon, J., \& Argiles-Bosch, J. M. (2017). The interaction effects of firm and partner tenure on audit quality. Accounting and Business Research, 47(7), 810-830.

Ghosh, A., \& Moon, D. (2005). Auditor tenure and perceptions of audit quality. The Accounting Review, 80(2), 585-612.

Hadi, A. S. (1992). Identifying multiple outliers in multivariate data. Journal of the Royal Statistical Society. Series B (Methodological), 54(3), 761-771.

Harris, K., \& Whisenant, S. (2012). Mandatory audit rotation: an international investigation (Doctoral Dissertation, University of Houston). Retrieved from https://uh-ir.tdl.org/ bitstream/handle/10657/ETD-UH-2012-05-372/HARRIS-. pdf? sequence $=2 \&$ isAllowed $=y$.

Healy, P. M., \& Palepu, K. G. (2001). Information asymmetry, corporate disclosure, and the capital markets: A review of the empirical disclosure literature. Journal of Accounting and Economics, 31(1-3), 405-440.

International Financial Reporting Standards (IFRS). (2018). Conceptual framework for financial reporting. London: IFRS.

Jenkins, D. S., \& Velury, U. (2008). Does auditor tenure influence the reporting of conservative earnings? Journal of Accounting and Public Policy, 27(2), 115-132. 
Jennings, M. M., Pany, K. J., \& Reckers, P. M. (2006). Strong corporate governance and audit firm rotation: Effects on judges' independence perceptions and litigation judgments. Accounting Horizons, 20(3), 253-270.

Johnson, V. E., Khurana, I. K., \& Reynolds, J. K. (2002). Auditfirm tenure and the quality of financial reports. Contemporary Accounting Research, 19(4), 637-660.

Kaplan, S. E., \& Mauldin, E. G. (2008). Auditor rotation and the appearance of independence: Evidence from non-professional investors. Journal of Accounting and Public Policy, 27(2), 177192.

Kim, H., Lee, H., \& Lee, J. E. (2015). Mandatory audit firm rotation and audit quality. Journal of Applied Business Research, 31(3), 1089.

Kim, S., Kraft, P., \& Ryan, S. G. (2013). Financial statement comparability and credit risk. Review of Accounting Studies, 18(3), 783-823.

Kwon, S. Y., Lim, Y., \& Simnett, R. (2014). The effect of mandatory audit firm rotation on audit quality and audit fees: Empirical evidence from the Korean audit market. Auditing: A Journal of Practice \& Theory, 33(4), 167-196.

Lawrence, A., Minutti-Meza, M., \& Zhang, P. (2011). Can Big 4 versus non-Big 4 differences in audit-quality proxies be attributed to client characteristics? The Accounting Review, 86(1), 259-286.

Lee, C. W. J., Li, L. Y., \& Yue, H. (2006). Performance, growth and earnings management. Review of Accounting Studies, 11(2-3), 305-334.

Li, D. (2010). Does auditor tenure affect accounting conservatism? Further evidence. Journal of Accounting and Public Policy, 29(3), 226-241.

Li, L., Qi, B., \& and Zhang, J. (2017). The effect of engagement auditors on financial statement comparability. Retrieved from https://ssrn.com/abstract=3047631.

Lowensohn, S., Reck, J., Casterella, J. R., \& Lewis, B. (2007). An empirical investigation of auditor rotation requirements. Retrieved from https://papers.ssrn.com/sol3/papers. cfm?abstract_id=1021789

Lu, T., \& Sivaramakrishnan, K. (2009). Mandatory audit firm rotation: Fresh look versus poor knowledge. Journal of Accounting and Public Policy, 28(2), 71-91.

McVay, S., Nagar, V., \& Tang, V. W. (2006). Trading incentives to meet the analyst forecast. Review of Accounting Studies, 11(4), 575-598.

Myers, J. N., Myers, L. A., \& Omer, T. C. (2003). Exploring the term of the auditor-client relationship and the quality of earnings: A case for mandatory auditor rotation? The Accounting Review, 78(3), 779-799.

Nagy, A. L. (2005). Mandatory audit firm turnover, financial reporting quality, and client bargaining power: The case of Arthur Andersen. Accounting Horizons, 19(2), 51-68.
Paulo, E., \& Mota, R. H. G. (2019). Ciclos econômicos e estratégias de gerenciamento de resultados contábeis: um estudo nas companhias abertas brasileiras. Revista Contabilidade \& Finanças, 30(80), 216-233.

Raiborn, C., Schorg, C. A., \& Massoud, M. (2006). Should auditor rotation be mandatory? Journal of Corporate Accounting or Finance, 17(4), 37-49.

Ribeiro, A. M. (2014). Poder discricionário do gestor e comparabilidade dos relatórios financeiros: uma análise dos efeitos da convergência do Brasil às IFRS (Tese de Doutorado). Universidade de São Paulo, São Paulo.

Ribeiro, A. M., do Carmo, C. H. S., Lopes Fávero, L. P., \& de Carvalho, L. N. G. (2016a). Comparabilidade X uniformidade dos relatórios financeiros: uma análise empírica durante $\mathrm{o}$ período de transição regulatória da contabilidade brasileira ao padrão internacional. Advances in Scientific \& Applied Accounting, 9(3), 262-282.

Ribeiro, A. M., do Carmo, C. H. S., Lopes Fávero, L. P., \& de Carvalho, L. N. (2016b). Poder discricionário do gestor e comparabilidade dos relatórios financeiros: uma análise do processo de transição regulatória da contabilidade brasileira. Revista Contabilidade \& Finanças, 27(70), 12-28.

Securities and Exchange Commission (SEC). (2003). Strengthening the Commission's requirements regarding auditor independence. Final Rule 68, File No. S7-49-02. Washington, DC: SEC.

Silvestre, A. O., Costa, C. M., \& Kronbauer, C. A. (2018). Audit rotation and earnings quality: An analysis using discretionary accruals. BBR - Brazilian Business Review, 15(5), 410-426.

Simmons, J. K. (1967). A concept of comparability in financial reporting. The Accounting Review, 42(4), 680-692.

Sohn, B. C. (2016). The effect of accounting comparability on the accrual-based and real earnings management. Journal of Accounting and Public Policy, 35(5), 513-539.

Verrecchia, R. E., \& Weber, J. (2006). Redacted disclosure. Journal of Accounting Research, 44(4), 791-814.

Wang, K. J., \& Tuttle, B. M. (2009). The impact of auditor rotation on auditor-client negotiation. Accounting, Organizations and Society, 34(2), 222-243.

Watts, R. L., \& Zimmerman, J. L. (1986). Positive accounting theory. Englewood Cliffs, NJ.

Wolf, F. M., Tackett, J. A., \& Claypool, G. A. (1999). Audit disaster futures: antidotes for the expectation gap? Managerial Auditing Journal, 14(9), 468-478.

Yip, R. W., \& Young, D. (2012). Does mandatory IFRS adoption improve information comparability? The Accounting Review, 87(5), 1767-1789.

Zhang, J. H. (2018). Accounting comparability, audit effort, and audit outcomes. Contemporary Accounting Research, 35(1), 245-276. 


\section{APPENDIX A - COMPARABILITY OF FINANCIAL REPORTS}

In this study, we used as measure of comparability the similarity of the accounting function, developed by DeFranco et al. (2011), with the adaptations proposed by Yip and Young (2012) and Ribeiro et al. (2016a). These authors made two adaptations to the accounting function similarity model. The first is replacing market value by the companies' total assets. Thus, the dependent variable of the first equation of the similarity metric for the accounting function consists of return as an independent variable and the net profit divided by total assets, that is, the Return on Assets (ROA). In the study by DeFranco et al. (2011), the market value proxy was used to isolate the effect of size on the measure. In this study we chose to use the asset, as it is a more consistent metric and does not present liquidity problems.

The second adaptation is to reducing the timeframe for calculating comparability from 16 to 12 quarters. According to the authors, this adaptation maintains the similarity properties of the accounting function and, consequently, properly captures the comparability of financial reports. This reduced timeframe allows more years of data for this the measure to be analyzed, since international standards became mandatory only as of 2010 .

Thus, to measure comparability, the first step was to estimate the accounting function for each company, considering the last 12 quarters, according to the following equation:

$$
\operatorname{ROA}_{i t}=\alpha_{i}+\beta_{i} \operatorname{Return}_{i t}+\varepsilon_{i t}
$$

where $\mathrm{ROA}_{i t}=$ quarterly net profit on the total assets for firm $i$ for non-consolidated period $t$; Return ${ }_{i t}=$ quarterly return for firm i for period $t$, calculated from the closing price of common shares, adjusted for dividends and splits.

Next, the parameters for the individual functions were estimated by individually projecting the firms' expected ROA [E (ROA)] based on the results of Equation (1). The [E (ROA)] equation is shown below:

$$
E(R O A)_{i i t}=\widehat{\alpha}_{l}+\widehat{\beta}_{l} \text { Return }_{i t}
$$

where $\mathrm{E}(\mathrm{ROA})$ iit = expected $\mathrm{ROA}$ for firm i with the parameters for firm $i$ for period $t$; Return $_{i t}=$ quarterly return for firm $i$ for period $t$, calculated from the closing price of common shares, adjusted for dividends and splits.

The expected ROA for the same company was also calculated with the estimators for other companies belonging to the same sector with the following equation:

$$
E(R O A)_{i j t}=\widehat{\alpha}_{l}+\widehat{\beta}_{l} \text { Return }_{i t}
$$

where $\mathrm{E}(\mathrm{ROA})_{i j i}=$ expected ROA for firm $i$ with the parameters for firm $j$ for period $t$; Return $n_{i t}=$ quarterly return for firm $i$ for period $t$, calculated from the closing price of common shares, adjusted for dividends and splits.

To maintain a constant economic event, we used the estimators for a company in an economic event of another company in the same sector. Thus, the measure of comparability of the companies is the average distance between the results obtained with Equation (2) and (3) for each quarter, that is: $\left[\mathrm{E}\left(\mathrm{ROA}_{i i t}\right)-\mathrm{E}\left(\mathrm{ROA}_{i j t}\right)\right]$. According to Equation (4).

$$
\operatorname{Comp}_{i j t}=-\frac{1}{12} \sum_{t-11}^{t}\left|E\left(R O A_{i i t}\right)-E\left(R O A_{i j t}\right)\right|
$$

where $\mathrm{Compb}_{i j t}=$ relative individual measure of comparability for firm $i$ based on firm $j$ for period $t$;

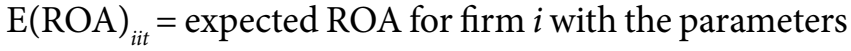
for firm $i$ for period $t$; $\mathrm{E}(\mathrm{ROA})_{i j i}=$ expected ROA for company $i$ with the parameters for firm $j$ for period $t$.

As comparability is a measure of distance between functions, the closer to zero the result for Equation (4) the more comparable are the firm pairs within each sector (DeFranco et al., 2011). The measure is multiplied by -1 to assess its growth using its upward curve, which facilitates graphical visualization and interpretation.
Equation (4) measures the average distances between the functions of two companies. After calculating these average distances between the reference companies, the measure of comparability for each company was obtained with the following equation:

$$
\operatorname{COMPM}_{i t}=\frac{\operatorname{Compb}_{i j t}}{n}
$$

where $\mathrm{COMPM}_{i t}=$ measure of comparability for each firm in relation to pairs within the same sector; Compb $_{i j t}$ $=$ measure of individual comparability for firm $i$ based on firm $j$ for period $t ; \mathrm{n}=$ number of companies in the sector. 
The firms with the highest mean comparability levels will be those with COMPM closest to zero, and the firms with the lowest comparability levels are those with the lowest COMPM values, that is, with values most distant from zero.

\section{APPENDIX B - CONSISTENCY OF FINANCIAL REPORTS}

The second measure of comparability we used in this study was comparability over time for a given firm. We called this measure consistency, in order to differentiate it from the original measure by DeFranco et al. (2011). This measure of comparability over time was originally adapted by Ribeiro (2014) and we used in this study to assess the effect of auditor rotation on the same firm in different years.

We chose to measure consistency measure due to the practical implications of this analysis. When a rotation of auditors or audit firms occurs, the understanding of certain accounting procedures carried out by the company may also change. This can change how a given economic event is recognized in the result and how users of financial information perceive the company's performance. In other words, analysts may think that there has been a change in the economic event, when in fact what has changed is the company's accounting understanding of it. As a result, auditor rotation may have a more negative effect on consistency than on comparability for users of financial information.

The same rationale used to measure comparability was used to measure consistency. An adaptation was made in the comparison parameter: instead of using the pairs within the same sector, the one-quarter lagged return for the same company was used, as shown in Equation (6).

$$
E(R O A)_{i i t}=\widehat{\alpha}_{\imath}+\widehat{\beta}_{l} \text { Return }_{t-1}
$$

where $\mathrm{E}(\mathrm{ROA})$ iit $=$ expected ROA for firm $i$ with the parameters for firm $i$ for period $t$; Return ${ }_{\text {it-1 }}=$ quarterly stock price return for firm $i$ for period $t-1$, calculated on the basis of the closing price of common shares, adjusted for dividends and splits, for the previous quarter.

Analyzing the economic event of a company based on estimators for a lagged period ( $\mathrm{t}-1)$ means assessing whether the company maintains information consistency over time in the face of economic events. In this sense, consistency is measured by the average distance of the functions obtained from Equation (2) and (6), for each quarter, $\left[\mathrm{E}\left(\mathrm{ROA}_{i i t}\right)-\mathrm{E}\left(\mathrm{ROA}_{i i t-1}\right)\right]$. The closer the results for these two functions the greater the consistency of the accounting information for the same company over time. Thus, to measure the intertemporal consistency for each company, we calculated the measure of closeness for each function, by quarter, using the following equation:

$$
\operatorname{CONSIS}_{i i t}=-\frac{1}{12} \sum_{t-11}^{t}\left|E\left(R O A_{i i t}\right)-E\left(R O A_{i i t-1}\right)\right|
$$

where CONSIS Cit $_{i}$ measure of relative individual consistency for firm $i$ based on firm $i$ for period $t$; $\mathrm{E}(\mathrm{ROA})_{i i t}=$ expected ROA for firm $i$ with the parameters for firm $i$ for period $t$; $(\mathrm{ROA})_{i j i}=$ expected ROA for firm $i$ with the parameters for firm $i$ for period $t-1$.
Unlike the measure of comparability, which is calculated based on the average distances between different companies, the measure of consistency is based on data for the same company over time. Thus, the result of Equation (7) consists of the company's consistency measure. 